\title{
Technology Nurtured - Collectives in Maintaining and Implementing Technology for Elderly Care
}

\author{
Sampsa Hyysalo
}

\begin{abstract}
Elderly care has become an increasingly appealing market for technology producers. Design for the elderly, however, often entails the meeting of two different worlds, one of young male high-tech professionals and one of elderly people and elderly care. This paper focuses on what happens to a new security technology making the transition between the two. Particular emphasis is laid on distributed and collective aspects of implementation and adaptation of new technology: networks of utilization and activities are discussed as pools of resources and interests for sustaining and shaping technology.
\end{abstract}

Key words: implementation, networks, elderly care

The move from design to use leads to two transformations for a technology. Its actual functioning becomes visible after all the visions and assumptions about how it should behave and how it is likely to be used. At the same time, the technology is literally passed from the hands of the designers to the hands of its users. It is no longer nurtured in a loving and technically competent environment, but expected to augment work tasks and fit into practices of users, who often do not share the enthusiasm and values of the designers, or their skills in tinkering with the technology (Engeström \& Escalante, 1996; Hasu, 2001).

This shift is particularly significant for health care and social care technologies. Their value rests on enabling new potentially improved or more efficient ways of doing things in the practices of care giving. But the change they induce is seldom neutral. It does not affect equally or even positively all the related people. Even when most patients and care givers benefit, some experience the technology as only an increase in their workload. Similarly, new arrangements tend to exclude some patients or complicate their care (Bowker \& Star, 1999; Berg, 1997). Neither is the introduction of new technology typically smooth or self-evident. While a successful tool results from a gradual convergence between the tool 
or procedure and the rest of the work practice (Berg, 1997: 161-165), such "convergence" often includes struggle or dismay when the technology hinders effective action or introduces unfit procedures. Even successful implementation may require significant efforts by users (Berg, 1997; Hasu, 2000; Hyysalo \& Lehenkari, 2002).

Elderly care is currently a venue where the success of the shift from designers to users is a crucial question. Research, news, and the experts interviewed emphasize that there is an ongoing transition in how the elderly live and are taken care of in Western industrialized countries. The amount of the elderly relative to workforce shall increase significantly during the next 30 years because of, among other things, the longer life expectancy, the retirement of the babyboomers, and changes in the family structures. The costs of care shall also rise, as the longer life-span is partially achieved through better but more expensive medication and hospital facilities. Politicians, care givers, and the elderly alike are faced with the question of how to manage this transition economically, as well as socially. The care of the elderly has come under significant pressure to change its established practices and values. In this situation, assistive technology holds a promise for re-organizing care (cf. Hempel, 1994).

Industry regarded seniors as an uninteresting consumer segment until the 1980s, but the demographic change has since made the market more appealing (Mollenkopf, 1994: 82, 85; Roe, 2001; Harrington \& Harrington, 2000). But industry awareness has not yielded much business so far. Many authors claim that a gap exists between what producers of- fer and the technical needs of the elderly (Törmä et al., 2001; Roe, 2001; Hyppönen, 1999).

The technology examined in this paper, Wristcare, offers a good occasion for examining the transition from telecommunications producers to the elderly and their care givers. Wristcare is a new generation safety-phone, but also a "semi-medical" technology. The device was designed to monitor user's physiological state from his wrist, and to generate an automatic alarm in case of medical emergency.

Experts have a hard time finding any telecommunications technology other than the Safety phone, which is designed specifically for the elderly widespread and positively recognized among the elderly and their care givers. The monitoring and automatic alarms in Wristcare may be seen as a welcome development, in which producers have taken seriously the needs of the elderly and responded with a serious product development project. Alternatively, the device may be regarded as another instance where technologists try to "push" more complex, alien, and cost-inducing technology into elderly care. Whichever the perspective, the case may reveal patterns and dynamics of how design and use are related in elderly care.

These concerns are tied to the fact that Wristcare, like many health care technologies are also technologies of security and control. On the positive side, Wristcare helps to control negative conditions, such as the effects and even the occurrence of illness attacks. But this is achieved by bringing an increasing part of the lives of patients / residents under the supervision of their care givers, as well as tightening their supervi- 
sion. This is not restricted to the control that the device as such exerts over its users, but also includes the control that needs to be exercised to ensure that the technology-mediated-security performs reliably (Berg, 1997; cf. McLaughlin et al., 1999; Grint \& Woolgar, 1997). In other words, the security comes at the expense of increased control and disciplining of the bodies and actions of the users to be docile enough for the technologically induced control to become and remain effective (cf. Foucault, 1995). These requirements imposed by technology are typically related to existing power relations, as different people have different access, competence, resources, and preferred mechanisms to make (or prevent) technology do things. They also have different power to affect the decisions and actions regarding technology within the organisations and their social relations (Wajcman, 1991; McLaughlin etal., 1999; Berg, 1997). The above is accentuated with Wristcare as it's end-users are elderly people and most care givers are women in low-paid professions, both peoples who are typically excluded (as well as tend to exclude themselves) from decision-making that concerns technology in their work and domestic life. This is particularly so in relation to design or altering the constitution of what is related to as "technical" and regarded as a domain for males and younger people (Wajcman, 1991: 143-146, 150-155; McLaughlin et al., 1999).

These aspects - new and increased forms of control, the built-in demand for change in the work practice, and the burden of making the technology to truly augment procedures and practices - accentuate the fact that the change from design to use also means a change in the criteria for the relevant characteristics of the technology. While a technology like Wristcare is likely to have an effect on users by guiding and constraining their possible actions (cf. Grint \& Woolgar, 1997; Latour, 1991), this designers' pre-figuration does not determine straightforwardly how it will be appropriated.

Literature on implementation and appropriation of technology has established that it is commonplace for the actual accomplishment of technology-mediated action to require work-arounds, artful integration of various technologies (Suchman et al., 1999; Suchman, 2002; Karasti, 2001), articulation work to keep things on the track (Clarke \& Star, forthcoming; Bowker \& Star, 1999), and reformulation of work practice, including the shaping of the technology in question (Hasu \& Engeström, 2000; Hasu, 2000; Karasti, 2001). Technology does not have intrinsic value, but its usability and value develop only by virtue of the actions and work done by its users (McLaughlin \& Skinner, 2000). Moreover, this creation of value is dependent on interaction, learning and meaning making between users, often seen to take place in relation to their existing personal, group and professional projects, as McLaughlin and her co-authors phrase it (McLaughlin et al., 1999; McLaughlin \& Skinner, 2000).

What these results imply is that "a technology" is not merely a singular device. Rather, a technology consists of and its effects depend on multiple venues of material and symbolic design: design of hardware and software components, design of products and product systems, design of local technical assemblage, design of socio-technical procedures in using and utilizing technologies, and the (re)design of personal and group projects, 
as well as the collectives in which artefacts are employed (cf. Williams et al., 2000; Stewart \& Williams, 2002; McLaughlin et al., 1999).

Much of this design takes place in different locations and by different parties: subcontractors, "producer company", assemblers, technical support people, home-care workers, nurses, relatives, and citizens such as the elderly. Technology producers, even in principle, cannot fully control all these aspects of sociotechnical configurations. At the same time, the success of the technology both for the producer and users - is fully dependent on achieving a locally valuable configuration out of the offers of a producer(s). The question is thus not only about how new technology shall affect the organization and quality of elderly care and life, but also, just as significantly, how elderly care and people shape and necessitate change in new technology and the organizations designing it.

This paper focuses on the last of these venues of design: the distributed and collective aspects of the utilization of technology. It seeks to offer a nuanced account of what is involved in implementing a technology and achieving a further work affording "design" in the practices of elderly care. The paper first elaborates on "networks of utilization", the socio-material configurations that technology like Wristcare must form across organisations to function. Second, it introduces how the seemingly distinct projects of residents, nurses, and managers are connected through the activity of a rest home. After this, attention is turned to the effects of these collective dimensions in the implementation of Wristcare in two rest homes.
The data analysed in this paper draws from the observations of and 35 interviews with residents, nurses, home-care workers and managers of four Finnish nursing homes for the elderly, during the years 2000-2001. In addition, the work and interaction in an alarm transmission centre was observed for a day in 2001, where interviews were conducted with the manager and the two workers of the centre. Interviews with three seasoned people in the maintenance and usertraining of safety phones gave further contextual understanding for the analysis. The discussion also owes its grounding to other studies of safety phone usage and the organisation of the alarm service (Östlund, 1995; Kaakinen \& Törmä, 1999; Wild \& Kirsschner, 1994; Törmä et al., 2001).

\section{Challenge of Creating and Maintaining a Network of Utilization}

Let us first briefly elaborate how the designers saw the use ofWristcare. The device consisted of a manual alarm button and sensors that gathered data about physiological indicators: Various kinds of movement (body and smaller movements such as pulse and breathing), temperature, and from the $2^{\text {nd }}$ generation onwards, also skin electroconductivity. The algorithms in the device and receiver unit combined these measurements to keep track of the changes in the condition of the user. This data was then transferred to control SW that provided messages for helpers. These messages included, on the one hand, various degrees of alarms, such as "acute disruption in condition," "disruption in condition,” or "extraordinary passiveness.” On 
the other hand, there were messages that related information about the state of the system, for instance a message ensued if the device had poor connection to the wrist, or was taken off, or if the connection was re-established. The number of these alarm-types changed throughout the period investigated, peaking at around 50, roughly half of which related to maintenance and the system's technical state.

In all, it was thought that these messages would allow the care givers to keep track of the typical gradually-worsening state of the elderly users, and thus allow them to take proactive measures, which designers believed would help to transform the practices of care giving. To augment this, the control software provided the history of the alarms of each user. The device was thought of strictly as a safety instrument, and any other kind of use was strongly discouraged in manuals, instructions, and so on. The response to alarms was ascertained by routing the alarms via a pre-programmed path, for instance, first to the control room, then to the cell phone of the nurse-on-call, and finally to an alarm centre, if nobody else had reacted. At the time this research was conducted the device was mostly used in institutions for assisted living, in which the elderly residents lived in their own separate apartments, but received help from the home-care workers and nurses if their condition deteriorated. These institutions were run by non-profit organisations, whose funding stemmed from the residents' monthly rents and subsidies from the city.

At first glance, Wristcare appears to be a fairly simple and highly automated system. Yet, its functioning depends on suc- cessfully aligning a rather impressive amount of technical and social elements. The list of relevant elements in utilizing Wristcare in sheltered housing grows painstakingly long. Before examining these elements in a more organized fashion, let us have a taste of the mundane complexity involved. The utilization depends on:

Residents of the nursing home, nurses, a manager, the architecture of the buildings, computers and the Wristcare control program, the radio-frequency transmission system and the telephone network, the pagers and cell phones used by all the staff, other security-technologies such as fire alarm systems and door surveillance, other software running in the computer such as the www-browser and e-mail, wheelchairs, patient lifts, residents' walking canes, the outside alarm centre to which the alarms are routed at night, the maintenance technicians of the company producing Wristcare (International Security Technology Ltd., IST) or their vendors, and often also relatives who instruct, help, and lobby for both the elderly and the staff of the rest home...

...just to mention a few prominent elements. Such a socio-technical configuration could also be called a network of utilization. Typical of such a network is that it has tightly and more loosely coupled parts, which are not derived from the design logic of the system, but arise largely from the other arrangements on which the network is built. The notion of coupling has been adopted from Perrow (1984) and Ratto (2003: 135140). It is used here in its fairly common sense meaning, denoting the intensity of the relations - interaction and dependencies - between the various humans 
and technologies in a unit (Perrow, 1999: 89-92). It thus differs from Perrow's more ambitious scheme for accident research that rests on differentiating between linear and complex interactions, as well as the tightness and looseness of couplings (Perrow, 1999: 93-99). This latter view seems to leave the intensity of interactions out of the notion of coupling, and thus to reduce coupling towards dependency only, which is not useful in the cases analysed here.

In the following, I shall first elaborate on some of the most prominent couplings and then examine the challenge involved in organizing them so they ensure the appropriate functioning of the network of utilization. Here network is understood as an ensemble of material and social elements that functions together. In contrast to system, its parts may not be primarily aligned with this particular functioning, but are parts in other networks and purposes. It is here discussed as a network, rather than networks of utilization, to emphasize how the utility of technology would collapse if some of the necessary elements of such a network were withdrawn.

\section{A Network of Utilization Results from Multiple Configurations}

A network of utilization for Wristcare can be seen to consist of a number of fairly tightly coupled and self-organized "subnetworks" and their interconnections. The notion of sub-network, however, suggests that the parts are subordinate and exist by virtue of the overall network. The more neutral notion of socio-technical configuration is more adequate here, as it better allows for discussing the efforts that go into achieving an appro- priate network of utilization out of a number of configurations. (See Figure 1.)

First configuration: around the wrist. The residents regularly met their relatives and the staff for all kinds of reasons, in which Wristcare is but a minor priority most of the time. At the same time, most residents were fairly unaware of the actions needed to secure the monitoring of the device. Frequently, the devices were worn too loosely on the wrist, not cleaned appropriately, or soaked while taking a shower or washing dishes (sometimes ruining the device). In general, most users did not know how to determine if the device still worked. In practice, to keep a Wristcare device up and running reliably, somebody had to check regularly the condition of the Wrist-device and how it was actually worn, and to perform test-alarms to ensure that the messages went through from the device to the transmission unit and onward to the care givers. Such an alignment did not take place automatically. The self-monitoring of the devices could not detect and inform nurses of all the possible malfunctioning. The responsibility for securing the functioning of the immediate technology was left to nurses and relatives that gave instruction on how to use it and checked on the devices. But there were limits to how often they were willing to go through the devices of the residents. Likewise, local arrangements were needed to develop successful ways of discerning the important alarms from the ones to be disregarded.

Second configuration, operability in a rest home. Every now and again there were problems either in some of the wrist-devices, the transmission or the software. When these problems piled up, 
Figure 1. A network of utilization.

In contrast to a system, people, technologies, organisational procedures etc. may not be primarily aligned with this particular functioning, but these socio-technical configurations also serve other purposes. This causes disturbances and tensions (lighting arrow and cut connection line) in the alignment, on which the technology (the dotted box) depends.

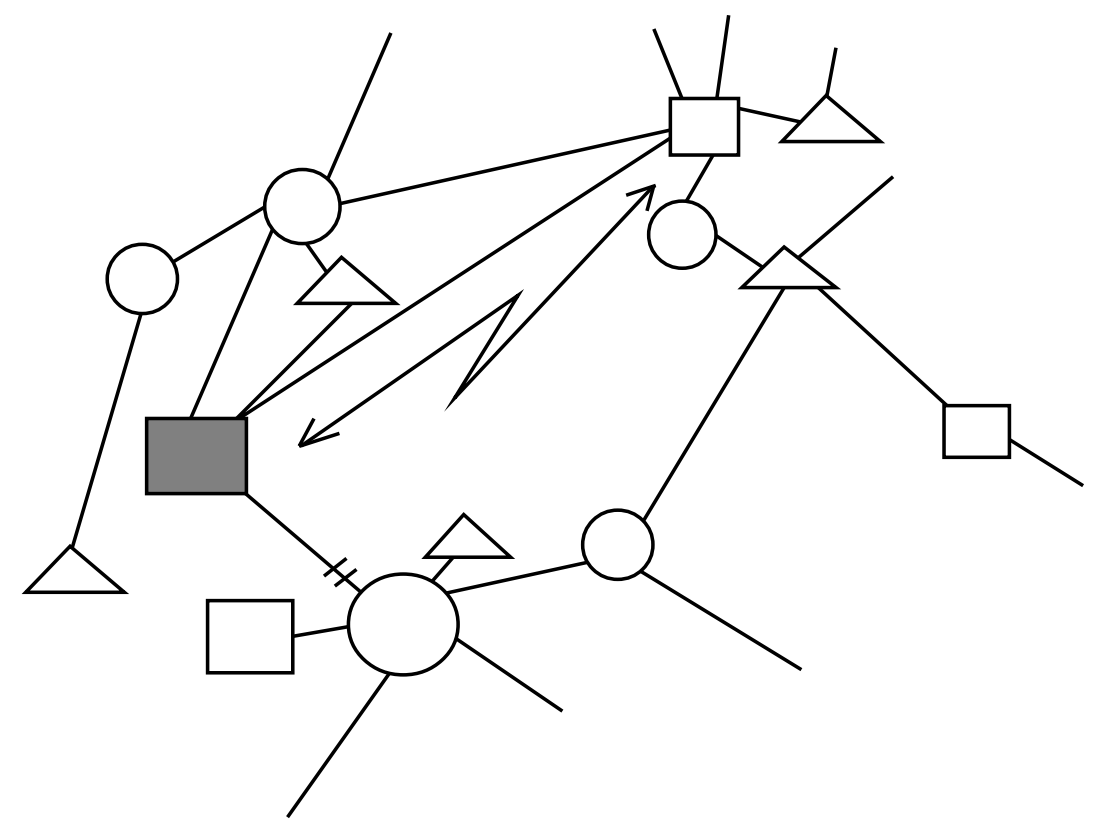

maintenance from IST or one of its local vendors came to fix things. The orientations of these two parties were rather different. While nurses and residents were concerned with the system augmenting their work and living, the maintenance people were mostly concerned that the system worked as specified. The changes made by maintenance people were sometimes superficially communicated to or understood by rest home staff, causing extra confusion.

The first and second configuration also affected each another. An illustration is a passiveness alarm coming from a resident whose device tended to interpret her drug-induced sleep as unconsciousness. As the typical hours for this incident were known by the nurse, they could infer whether an alarm was false or not. When there was a maintenance visit affecting many parts of the system, the nurses would need to question which of their practical arrangements could still be trusted. Residents often just experienced the changes without knowing that something had been altered in the system.

Third configuration: the alarm-centre. During the night some rest homes were unmanned and the alarms routed to an alarm centre. This configuration consisted, on the one hand, of the nurse in the alarm centre with her software and phone, and, on the other hand, of the system in the rest home. These two parts 
were loosely coupled: The SW in the alarm centre was the only link between the two, yet it conveyed little information about the condition and particularities of the resident or the rest home system (that were personally encountered by nurses in the rest home). In addition, the pace of work and routines in the alarm centre effectively prevented a thoroughgoing use of the diagnostic software. Finally, as this was during the night, establishing a link between the alarm centre and the resident meant waking up the resident, thus adding to the difficulty in making decisions about the right action. As a result, the alarm centre categorically appealed to their normative responsibility to check all alarms by calling, which frustrated the residents that were woken up in vain. Another instance of the same gap was that the rest home did not necessarily receive all the relevant information about the events of the night from the alarm centre ...where the shift may have been changed before the nurses in the rest home came back to work.

\section{Appropriate Action and Alignment}

The functioning of the network of utilization for Wristcare depends on how appropriately different configurations and elements within them can be coupled. Some of the preconditions for the appropriateness of the couplings arise from the economical and moral aspects of Wristcare. While Wristcare is worn continuously, the incidents it protects against happen rarely. Its value depends on being able to transmit alarms reliably 24 hours a day, for weeks and months. This sets limits both on how extensive (and expensive) alterations can be made to existing work procedures, and how many false alarms and other nuisances the system can be allowed to generate. While Wristcare uses some of the infrastructure and services designed for traditional Safety phones, it is more complex and produces more of both wanted and unwanted alarms. At the same time, the system sets high requirements for the speed and reliability of the responses to the alarms. The stakes are considerable, as a life may be on the line, yet it is equally established that the gross majority $(60-97 \%)$ of the alarms do not require sending in an ambulance, and doing so as a precaution generates unbearable costs for the service (Ihonen, 1987; Östlund, 1995; Wild \& Kirsschner, 1994; Kokko \& Ekberg, 1993; Kokko, 1997; 1998; Soosalu, 1996).

The challenge in organizing a network of utilization consisted of nurturing, as well as of transforming the existing configurations. The nurturing challenge lay in recognizing what kind of "naturally occurring" configurations the technology enters. As in the case of Wristcare's first configuration, such a configuration may be fairly tightly coupled, and may prove self-organizing in dealing with new technology. Literature abounds with examples of how users manage poor interfaces, insufficient functionality, or operational models that do not fit their way of handling the device. Such shaping includes creating work-arounds, artful integration with other technologies, creating unanticipated ways to manipulate the interface, direct changes in the physical characteristics of the technology, and leaving unattended some features of the technology. Many of these immediate actions to re-figurate technology were also encountered with 
Wristcare: augmenting software by scribbling notes on pieces of paper, replacing the diagnostic procedure in the system by an in-depth knowledge of residents' daily rhythms, creating ways to use a cell phone with the system, changing the emergency-button into a general nurse call, and so on. The various workarounds and local procedures that emerge to deal with the technology may become useful cues in improving the technology, and user manual.

Yet not all necessary couplings are readily available in the existing work practices. As in the case of the third configuration (division of labor in a rest home and an alarm centre), the successful coupling required creation of new connections, procedures, and instruments to align the loosely coupled configurations. The rest home's and alarmcentre's different relation to alarms and different logic in answering them created a persistent source of problems for the use and maintenance of the technology. These conflicting priorities and logics of action required that the company re-designed the control SW so that only the most urgent messages (requiring calling up the resident in any case) went through and were reacted to at the alarm centre. In other words, the company had to re-align the coupling with these two localities by changing the mediating technology. This is quite planned transformation and redesign, instead of nurturing the ways users tinker with the technology within existing configurations (cf. Ratto, 2003: 134-136). In both cases, an appropriate alignment is about examining if there are such tight couplings, particularly dependencies, that need to be made less binding and linear, and reciprocally, loose connections that need to be made tighter to avoid disturbances and bottlenecks in the working of the network of use.

The key point here is recognizing the importance of both nurturing and redesigning in achieving an appropriate coupling. In the Wristcare case, technology producers' aim to redesign tightly coupled configurations anew proved unrealistic in the work practices of nurses. Similarly, the aim to leave all the couplings to users proved just as detrimental for the achieving of useful and commercially successful technology: a more cooperative relationship was needed to work out acceptable couplings to all implicated parties in terms of costs as well as functioning, such as reliability (Hyysalo, 2004).

\section{Activities as Sources of Resources and Interests}

The network of utilization drew attention to how the functioning of technology required couplings between multiple configurations of projects and instrumentalities. It is thus an artefact centric perspective to the collectivity related to technology, coming close to the ANT/ SCOT notion of (heterogeneous) ensemble (Law \& Bijker, 1992). Attention is now turned to a different kind of collectivity around technology. The projects of users make sense only in relation to other projects and instrumentation in a rest home. Such a systemic whole may be discussed in terms of an activity system. An activity is a formation of relatively long-lasting or durable collective action that often takes the shape of an institution. It is comprised of a community of participants that has a social organisation and the means to pursue its aims. 
Activities are animated by shared motives that are materialized in the objects the activity is engaged in transforming (Leontjev, 1978; Engeström, 1987).

Rest homes may be characterized as this kind of relatively stable socio-material formations. A good example is the rest home "Silverhair" in Espoo. It was founded in the early 1990s as one of the many recent "Palvelutalo" (Lit. service house) to fill the gap between independent living at home and the institutions for the elderly in rather weak condition. The community consists of residents, home-care workers, nurses, and a manager. They have a set division of labour among them: Care and assistance is provided by the personnel, while residents try to manage their life as well as they can while accepting some loss of selfresponsibility. This division of labour is materialized in explicit and implicit rules about how people should behave in their homes, and while eating, bathing, giving and taking treatment and in socializing with others in public spaces.

The actions of participants are socially mediated by, for instances, routines, social events, greetings and conversations among members. Tools and signs, such as medications, telephones, Safety phones, and instructions, also mediate the actions of all members. An important mediator is the special layout of the seniors' apartments and the building in general. It provides each resident with his/her own apartment and private sphere, but is equipped so that the staff can provide help for those who need it. The above aspectsof activity are interconnected by the motive (by and large) shared by the participants: enabling a meaningful and safe ageing for the residents, who can no longer manage or wish to live in their original apartments. Its materialized outcome is the mainte-

Figure 2. The elements of elderly care in a rest home depicted as an activity-system.

Tools and signs: Care-rounds, conversations, medications, fire and door alarms, telephones, safe ty-alarm /

Wristcare, etc.

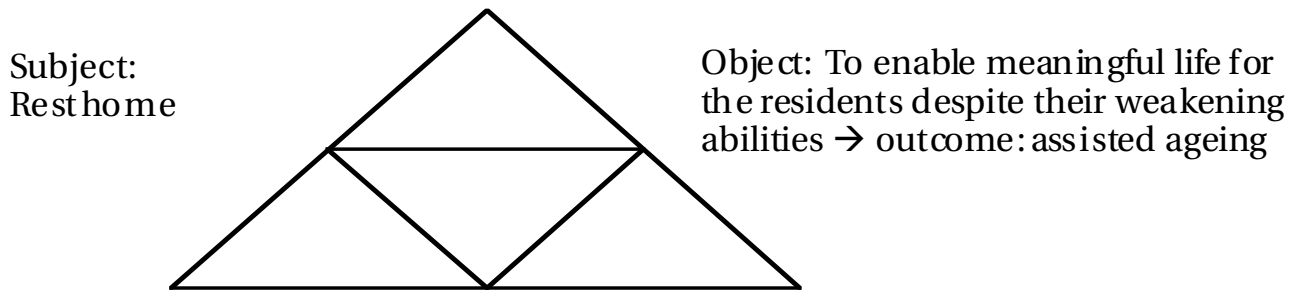

Rules: about conduct in eating, bathing, treatment and in the social sphere
Community: Residents, homecare workers, nurses, a manager
Division of Labor: Care provided by the personnel, residents manage as well as they can, and accept the loss of some self-responsibility 
nance of the physical and social well being of the residents. The State, the residents, and their relatives, who fund the institution, recognize this outcome. Such an activity system may be modelled as in Figure 2 (cf. Engeström, 1987: 78)

Wristcare enters this activity as one of the new means mediating the interaction between the staff and the residents. It takes on a variety of roles in the division of labour and rules of the community, yet its importance should not be over-emphasized among the well established routines, means, and identities of the home-care workers, nurses and residents.

\section{Activities and Networks of Utilization in Implementing New Technology}

It is now time to put the introduced elements into action in comparing two implementations of Wristcare in sheltered housing during the years 2000-2001. In the city of Espoo, the implementation turned into a struggle, while in Turku, the system was implemented with a rather high level of satisfaction among workers and relatively little worry for the rest home. The differences between these two extreme cases in satisfaction with the system can be partly explained when they are analysed in terms of the resources and arrangements the two rest homes had for implementing Wristcare, as well as by looking at the resources and priorities found in the network of utilization during the implementation.

The two institutions were roughly identical: both were "palvelutalo", institutions for assisted living, built recently, and equipped with all the latest solu- tions for elderly care. Both also had special facilities for housing demented residents, and were staffed accordingly. They were relatively large and clearly "flagships" of the foundations that ran them. Within them, the Wristcare system comprised all those living in their own apartments wanting the device, and all those suffering from dementia. Alarms were routed to cell phones and the control software was in the nurses' office. As both institutions were manned 24 hours a day, no outside alarm centre was involved.

\section{Espoo Implementation in Brief}

The Espoo site was a brand new institution, and Wristcare was one of the many technologies that were installed. The technologies all came from different providers and it soon appeared that nobody had the overall responsibility for the complex electronic and telecommunications systems, which kept on causing hassles. The difficulties were accentuated with the residents moving into the rest home before the construction of the building and its various technologies was finalized. At the same time, IST was in the middle of a struggle to master the initial bugs in their second generation of the device and, as a consequence, could only provide devices from the first generation, ridden with reliability problems.

In implementing the Wristcare system, the rest home strictly followed the producers instructions on how the devices were to be worn and alarms responded to, to ensure maximally reliable monitoring. The advice on how to get started with the system, offered by the foundation's other rest home, was turned down. The expectation was that all the 
technical systems should function the way the suppliers had promised, or, more to the point, as conveyed by their sales pitch. Within the rest home, no-one in particular was appointed to be responsible for the implementation of the various technologies or to work out appropriate procedures for how to deal with them.

Some of the elderly residents had difficulties in understanding even the basic idea of the device, not to mention the technically oriented instructions that were quite removed from their daily life. The result was that residents then suffered, for example, from too tight bracelets and false alarms, while the technol- ogy suffered, for instance, from being worn too loosely, or being destroyed by water in the shower. Once it became clear that all of the instructions could not be followed, the staff faced the difficulty of determining which of the instructions in the multi-page technical manual were the ones that really had to be enforced. With the recurring problems and changes in the instructions, some of the residents began to lose their confidence in the system. The staff, in turn, experienced this as having to listen to the residents' frustrations with the technology, along with their own growing frustrations related to how they should go about diagnosing and responding to the alarms and man-

Figure 3. The network of activity systems around the rest home in the city of Espoo.

All technologies were supplied and assembled by different companies, and all implemented at once, while the rest home itself was ran amidst the final stages of its construction.

Means: Delayed design process

IST

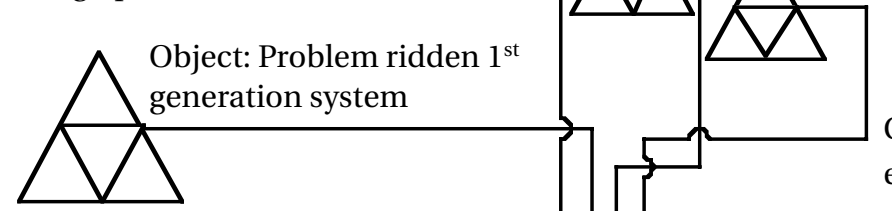

Construction and electricity companies

Organisation: Under pressure and transformation

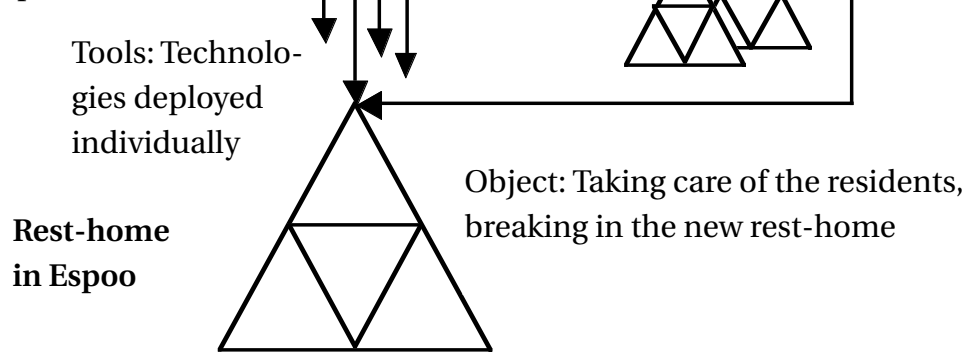

Organisation: Still under formation 
aging the various technical systems.

Amidst all the problems, the rest home manager also struggled to find (and to keep in) enough competent staff for her new institution, the vendors had to deal with accumulating complaints, and finally, IST had to deal with frequent product replacements, extra training sessions, ongoing complaints, and gained few ideas for improving the device in the future. It took over a year before the rest home and the company had managed to work out all the details to make the system work technically, and to create appropriate procedures to fit the system to work practices. In other words, while there was a fair amount of company involvement, it was slow to yield the results hoped for by both parties. (See Figure 3.)

\section{Turku Implementation in Brief}

In contrast, the rest home in Turku allied itself with a local telecommunications vendor, who wanted to start selling Wristcare and other rest home telecommunication electronics in the region. Even though the process in Turku and in Espoo began at roughly the same time, the Turku site rejected any temporary solutions and waited until IST was able to provide the 2 nd generation system ordered. The technical assembly was handled by the vendor, who faced the difficulties (not unlike those in Espoo) in making the system fit the rest home and its other technical systems. The deal with the vendor buffered the rest home against the significant economical losses associated with the initial difficulties. The deal also provided a much stronger position to negotiate with the supplier company IST, as it was expected by all parties that future sales would follow in the region if the Turku site proved successful.

In the rest home, the implementation and development of work procedures were discussed and customized on a weekly basis in a staff meeting. In addition, the process was assigned as the special responsibility of one technically more competent nurse. As in the Espoo site, initially also Turku strictly followed the producer's instructions and reacted to all alarms that the system generated. They also experienced this as a burden. But in Turku modification of the system began as soon as they had some experience of how it worked. For instance, they ceased to react personally to "off/on the Wrist" notices, and extended the time frame in which the automated function in the system informed about this. They also profiled the monitoring for those users who experienced inconvenient amounts of false alarms. At the same time, the staff instructed the residents, who gradually learned how to wear and clean the device, and what not to do with it, which reduced the amount of false alarms and the inconvenience for the users.

The better position of IST and the alliance with the vendor seemed to have helped the Turku site in customizing the system for their needs. The people at the Turku site expressed that they truly benefited from the three occasions the IST people came to upgrade the control software, to replace malfunctioning devices, to gather feedback about the system, and to give additional information about it. At the time of my inquiry, about three months after the implementation, both residents and staff expressed that the system was running fairly smoothly, even though the company had not met 


\section{Figure 4. The network of activity systems around the rest home in the city of Turku.}

Telecommunications vendor buffered the rest home technically and economically, while also IST and the rest home itself could devote sufficient resources to the implementation of Wristcare

Means: Capability to produce $2^{\text {nd }}$ generation

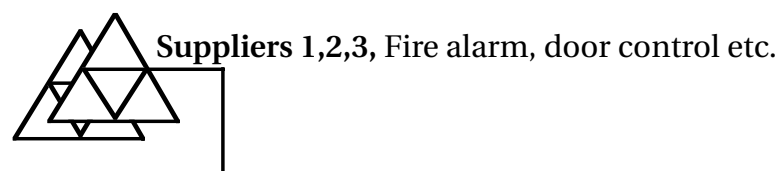

IST

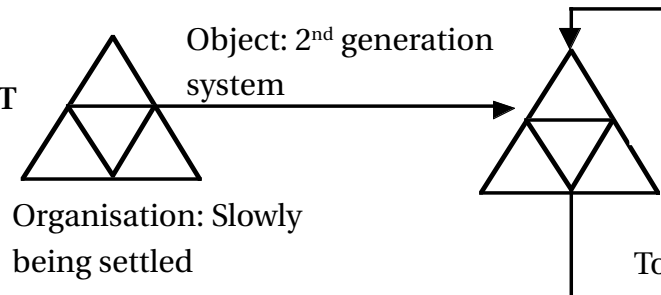

Telecommunications vendor, exclusive deal, buffers the rest-home technically and economically

Organisation: Slowly being settled

Tools: Gradually implemented, help

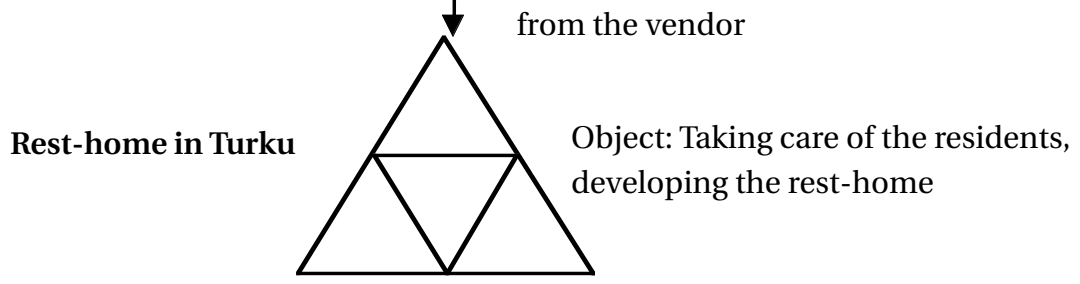

Organisation: Partly under formation

all their key requests for improvement. (See Figure 4.)

\section{Comparing the Implementations}

Some of the differences in these two cases may be attributed to the quite formidable changes that happened in the Wristcare system between 2000 and 2001, but there seems to be more than that involved. The difficulties in Espoo or the success in Turku do not seem to be derived from any one part of the network; rather, they were the gross sum of interactions between the actors that further affected one another.
The examples point to the importance of the collective resources within the activity: people mediating each others actions (other residents, other nurses, a manager) and the practices that had been created to deal with technologies, in general and the implementation of new systems, in particular. People helping each other out with tasks and artefacts, alongside their main job, have been characterized as "informal intermediaries" in appropriation of technology, in contrast to people whose main job it is (Williams et al., 2000: 155). The informal intermediaries points further to the importance of unrecognized, "in- 
visible," articulation work that goes on keeping things on track in organisations (Clarke \& Star, forthcoming). In Espoo, there were multiple technologies that needed to be implemented at the same time, while the staff had no clear responsibilities or a strategy to deal with the creation of appropriate procedures and the unexpected shortcomings of the technologies. In Turku, a more positive spiral was formed, as the staff could focus more on the implementation of this particular technology. This enabled them to give clear and understandable instructions to residents whose learning to wear the device turned out to be a major issue in reducing the drawbacks of the system. The site in Turku also had more previous experience in implementing new technology, and thus may have been better prepared for the nature and demands of the implementation.

Second, these cases support Williams et al.'s (2000) conclusion on the importance of the "appropriation intermediaries” (Williams et al., 2000: 156-158) in the appropriation of new ICT. While the Espoo site was left to grapple with a chaos generated by many partially working technologies, Turku was significantly supported by its vendor. The vendor helped to configure the technical system at a site in a specific way and to integrate it with other technologies, such as cell phones, and helped to fix the bugs and needed work-arounds that ensued, acted as an available source of help and information about the system, and finally, added power to request improvements from the supplier company. Another important intermediary role was that of the rest home managers. They organized the deals, the relationship with vendors, various supplier compa- nies and funding bodies, and how the implementation process was handled within their organisation.

The cases of the two rest homes are also illustrative in regard to the access that different stakeholders have to technology. The discussion on access typically concentrates on the immediate access to change the technology in use (Ratto, 2002). Residents' access to bringing about change in the system (for instance in taking measures to avoid false alarms) was almost wholly dependent on the nurses, and thus on mobilizing other people. Nurses, in turn, could make work-arounds and adjustments with administrator passwords or an appeal for help from the vendor's or IST's maintenance personnel. All of these actions also required negotiation and resources, both inside the rest home (manager and other nurses) and with the other stakeholders in the network of utilization. The collectivity and mutual dependencies in access to technology in use are equally present with the vendors and the supplier. Even though they could tinker more effectively with the technical devices, they were dependent on the nurses in regard to how the system was actually being deployed and used locally.

Such dependencies between the users become much more accentuated when the "deferred access" is examined. Deferred access here means actions that bring about change in the system in the long run, particularly re-designs that exceeded what could be solved on the spot (Ratto, 2003; 2002). An instance of this was that a rest home could attract IST to fix obvious and persistent minor bugs to make the installation run smoother. Such local bug fixing was not very attractive for the company, and it was much 
easier to accomplish this with the power of a vendor alongside the Turku site. Once the company entered to enable this kind of access, its prime motive was (in addition to meeting the contract and guarding its reputation) in the second kind of deferred access, namely, to improve its general product offer by a version upgrade based on the wishes and complaints reported from a number of users sites. The company gradually learned to foster relationships with its clients in order to accumulate ideas for an extensive redesign of the system. This exemplifies how the forms of access available, both for the users and for the supplier company, depend on how they manage to attract the other users necessary for the functioning and improvement of the network of utilization.

Finally, the cases of the two rest homes provide some input for the discussion about the mutual adaptation between technology and organisation: the growing awareness of the importance of the unexpected new uses for new technologies (Rosenberg, 1979; Leonard, 1995; Schot \& Bruheze de la, 2001). As the studies in learning-by-using suggest, a producer benefits from the experiences of technology users concerning prerequisites, restrictions and best practices. The advantages come through conveying this knowledge to new clients, to vendors, and to other intermediaries involved in doing local configuration work, as well as back to its own R\&D department for re-design work (e.g. Rosenberg, 1982). The case of two rest homes simply suggests that the extent and speed that the mutual adaptation takes place depends on its starting points. The rest home in Turku had more mature version of Wristcare and more resources for adopting and adapting the technology. Not coincidentally, it was quicker to adapt its work practices, to drive in improvements for the technology, as well as quicker to provide suggestions for the long-run development of the technology.

In other words, while designers should not expect to fully determine the use of technology in advance, the expectation of mutual adaptation hardly relieves designers from the effort of making the technology fit the practices of use in the first place. The ways of using are prefigurated in the material constitution of the technology in the design process. While not carved in stone, it takes time, effort, and desire on the part of the users to start modifying new technology, and they can hardly be expected to do so if the technology does not seem promising enough for their purposes and usable enough to invite experimentation with it (cf. Hasu, 2000). This may be even more so with regard to current claims about the shortening of product development life cycles: products that fit poorly with the practices of users may not evoke much feedback, and thus provide poor starting points for the following design generations.

\section{Conclusion}

This paper studied the collective and distributed aspects of technology utilization. Two different kinds of collective constellations were distinguished. First, the network of utilization served as a means to discuss the immediate collectivity around technology: those elements that kept the technology functioning. Such a network was seen as composed of multiple socio-technical configura- 
tions and their couplings.

The functions of the three key configurations for the use of Wristcare may be found in other technologies as well. The first configuration (around the wrist) points to the immediate interactions in utilizing and maintaining technological devices by their "end-users." The second configuration (securing the operability in a rest home) draws attention to the often invisible work various implicated users do to keep technical systems up and running and adapting them to the work projects. The third configuration (alarm-centre and rest home) is an instance of an inter-organisational distribution of roles and responsibilities often necessary for achieving the eventual utility the technology promises to offer.

The key finding was that all the necessary parts of such a network could not be feasibly built up just for Wristcare. In practice, this meant that the configurations on which the network of utilization rested were constructed and maintained for some other purpose, and in being so, they were usually sub-optimal for the technology designed. Neither were the couplings between the configurations always natural. Instead, time and resources were required to find appropriate ways to alter and bridge the resources and goals of different participants. Some of these existing connections offered themselves to be quite readily nurtured to better supportWristcare, while other connections needed to be explicitly built up just for the task. The latter, even if more logical from a design point of view, required substantially more resources. This is arguably the case with most other technologies, as well. This is a point to remember for technol- ogy designers who typically aim to predefine their technology from their own logic rather than from the users workpractice onwards, and arguably thus often adopt less flexible and less economical ways to achieve appropriate couplings for their technology.

It is vital to analyse what kinds of other purposes and collectivities a network of utilization builds upon. One way to do this is to look at the stabilized collectivities in terms of activity systems. Such a systemic view helps to analyse the different motives, rationales for participation, as well as the way the collective is organized. It allowed discerning how the combined effects of local activity, and the network built around technology, came to have a decisive effect on the way Wristcare could be utilized in the projects of nurses and residents, and of other stakeholders in the two rest homes.

At the outset, it seemed that Wristcare was a case where technologists imposed new and potentially foreign procedures and values on elderly care. Key design features, such as introducing the continuous monitoring of relatively healthy residents, allowing (and demanding) that home-care workers shift from reactive measures to pro-active control of the residents' physical condition, as well as seeking cost-saving through technicallysupported extra-mural care, may all lead to major externally induced transformation of elderly care and living. The question could be posed as to whether it is in the best interest of elderly care to be so technically transformed. Indeed, it would seem that the project truly exemplified the separation of design and use as well as the dominance of design over use, that are arguably common in the 
design for elderly care and in the design of new technology, in general.

Yet, such an emphasis on determining the power of technology is not fully supported by the analysis. Wristcare mostly added a layer of technically mediated monitoring of residents and made some procedures more flexible, such as care rounds in work practices. Neither did it replace work force or diminish personal care for residents in any of the sites studied. The technology of replacement and transformation seems to have been domesticated into a supporting tool within the pre-existing models for services and institutions. Such a shift turns our attention to the other side of the separation of design and use: what happens to the technology following its significant re-definition in users' hands. Yet, should the kind of security offered by Wristcare normalize and establish its reliability in the future, its transformative potential may still gradually shape elderly care, whatever the technology and the practices of care may be at that point.

\section{Acknowledgements}

I want to thank Prof. Reijo Miettinen, Prof. Päivi Eriksson, Prof. Geoffrey Bowker, Dr. Sirkku Kivisaari and Dr. Matt Ratto for their helpful comments with earlier drafts of this paper. The preparation of the manuscript was made possible by funding from the ProAct reseach programme funded by the Finnish Ministry of Trade and Industry and TEKES.

\section{Notes}

1 Both my own interviews, other research (Törmä et al., 2001) and company experience agree that during the years 19982002 , most of the elderly wearing the device were 70-90 years old, and already in a fairly weak condition. Many had severely hampered vision and hearing, sometimes also problems with cognitive abilities, all of which placed a burden on using and learning a new technology. The majority of them had little experience with the latest technologies, such as wireless communication or physiological monitoring.

2 Interviews with the manager 01.09.2000, and the project manager of the foundation owning the institution 30.08.2000.

3 Interview with the nurse $\mathrm{M}$ and the manager 01.09.2000.

4 Interview with the manager and nurse $M$ 1.9.2000.

5 Observation and interviews with nurses $\mathrm{M}$ and $\mathrm{P}$ 01.09.2000.

6 Recording of the IST training session 06.09.2000; Discussions with IST designers 12.09.2000.

7 Interview with the rest home manager 08.11.2001.

8 Interview with the rest home manager 08.11.2001; nurse L 12.11.2001.

9 Interview with nurse L, 12.11.2001.

10 Interview with nurse L 12.11.2001; and nurse La 08.11.2001.

11 Interviews with nurses and managers 08.11.2003 and 12.11.2003.

\section{References}

Berg, M.

1997 Rationalizing Medical Work. Cambridge, MA: MIT Press.

Bowker, G.C., \& Star, S.L.

1999 Sorting Things Out: Classification and its Consequences. Cambridge, MA: MIT Press. 
Clarke, A.E., \& Star, S.L.

Forthcoming "Symbolic Interactionist Science, Technology, Information and Biomedicine Studies". In L.T. Reynolds \& N.J. Herman (Eds.), Handbook of Symbolic Interaction. Walnut Creek, CA: Alta Mira Press.

Engeström, Y.

1987 Learning by Expanding. An Activitytheoretical Approach to Developmental Research. Helsinki: Orienta-Konsultit Oy.

2000 "Activity Theory as a Framework for Analyzing and Redesigning Work". Ergonomics, 43(7): 960-974.

Engeström, Y., \& Escalante, V.

1996 "Mundane Tool or Object of Affection? The Rise and Fall of the Postal Buddy". In B. Nardi (Ed.), Context and Consciousness. Activity Theory and Human Computer Interaction (pp. 325-374). Cambridge, MA: The MIT Press.

Foucault, M.

1995 Discipline and Punish: The Birth of the Prison. New York: Vintage Books.

Foucault, M., \& Gordon, C.

1980 Power/knowledge: Selected Interviews and Other Writings, 1972-1977. New York: Pantheon Books.

Grint, K., \& Woolgar, S.

1997 The Machine at Work: Technology, Work, and Organization. Cambridge, UK: Polity Press.

Harrington, T., \& Harrington, M.

2000 Gerontechnology. Why and How. Maastricht: Shaker publishing.

Hasu, M.

2000 "Constructing Clinical Use: An Activitytheorectical Perspective on Implementing New Technology.” Technology Analysis \& Strategic Management 12: 369-382.

2001 Critical Transition From Developers to Users. Academic dissertation. Helsinki: University of Helsinki, Department of Education.

Hasu, M., \& Engeström, Y.

2000 "Measurement in Action: An Activitytheoretical Perspective on Produceruser Interaction." International Journal of Human-Computer Studies 53(1): 6189.
Hempel, J.

1994 Opportunities and Limitations of Technical Aids for the Elderly. In C. Wild \& A. Kirschner (Eds.), Safety-alarm Systems, Technical Aids and Smart Homes (pp. 101-114). Knegsel: Akontes Publishing.

Hyppönen, $\mathrm{H}$.

1999 Handbook for Inclusive Design of Telematics Applications. Helsinki: Stakes.

2004 Tekniikka kehittyy, kehittyvätkö palvelut? Tapaustutkimus kotipalvelujen kehittymisestä teknologiahankkeessa. (Technology Develops, Do the Services Develop? A Case Study About the Development of Home-care Services in a Technology Project). Helsinki: Stakes.

Hyysalo, S.

2004 Uses of Innovation. Wristcare in the Practices of Engineers and Elderly. Academic Dissertation. Helsinki: Department of Education.

Hyysalo, S., \& Lehenkari, J.

2002 "Contextualizing Power in Collaborative Design.” In T. Binder, J. Gregory \& I. Wagner (Eds.), Pdc 2002, participatory design conference 23.-25.6.2002 (pp.93104). Malmö, Sweden: Computer Professionals for Social Responsibility.

Ihonen, $\mathrm{M}$.

1986 Vanhusten ja vammaisten turvapalvelussa käytettävät laitteet ja järjestelmät (Devices and systems used in the security services for the elderly and the disabled) (Sosiaalihallituksen raporttisarja). Helsinki: Sosiaalihallitus.

1987 Turvapalvelut. Vanhusten ja vammaisten turvapuhelin kokeiluprojektin raportti (Safety services. The report of pilot study on safety phones for the elderly and the disabled). Helsinki: Sosiaalihallitus.

Karasti, $\mathrm{H}$.

2001 Increasing Sensitivity Towards User Practice in Systems Design. Academic dissertation. Oulu: University of Oulu, Department of informatics.

Kaakinen, J., \& Törmä, S.

1999 Esiselvitys gerontologiasta - ikääntyvä väestö ja teknologian mahdollisuudet (Prestudy on gerontechnology - the ageing population and the possibilities of technology) (Vol. 2/1999). Helsinki: Eduskunnan Kanslia. 
Kokko, J.

1997 “Turvapuhelinjärjestelmät ovat yleistyneet kiitettävästi suomessa" (Safety phone systems have become more common in Finland). Kunnalliselämä 7(11): 58-61.

1998 “Turvapuhelinjärjestelmän uusiminen tai laajentaminen" (The renewal or expansion of a Safety phone system). Kunnalliselämä 1.

Kokko, J., \& Ekberg, J.

1993 "Turvapuhelinjärjestelmien leviäminen suomessa" (The proliferation of Safety phone systems in Finland) Helsinki: Stakes Unpublished manuscript.

Law, J., \& Bijker, W. E. (Eds.)

1992 Shaping Technology/Building Society: Studies in Sociotechnical Change. Cambridge, MA: MIT Press.

Leonard, D.

1995 Wellsprings of Knowledge: Building and Sustaining the Sources of Innovation. Boston, MA: Harvard Business School Press.

Leontjev, A. N.

1978 Activity, consciousness, and personality. Moskow: Progress.

McLaughlin, J., Rosen, P., Skinner, D., \&

Webster, A.

1999 Valuing Technology: Organisations, Culture, and Change. London: Routledge.

McLaughlin, J., \& Skinner, D.

2000 "Developing Usability and Utility: A Comparative Study of the User of New IT.” Technology Analysis \& Strategic Management 12: 413-423.

Mollenkopf, $\mathrm{H}$.

1994 "Technical Aids in Old Age - Between Acceptance and Rejection." In C. Wild \& A. Kirschner (Eds.), Safety-alarm Systems, Technical Aids and Smart Homes (pp. 81-98). Knegsel: Akontes Publishing.

Perrow, C.

1999 Normal Accidents. LivingWih High-risk Technologies. Princeton, NJ: Princeton University Press.

Ratto, M.

2002 "Conceptualizing Design as an Activity of Re-working." Paper presented in Dealing with diversity, International Society for Cultural Research and Activity Theory (ISCRAT) 18-22.6.2002.
2003 The Pressure of Opennes: The Hybrid Work of Linux Free/open Source Kernel Developers. Academic dissertation. San Diego: University of California San Diego, Department of Communication.

Roe, P.R.W. (Ed.)

2001 Bridging the Gap? Access to Telecommunications for All People. Lausanne: Commission of European Communities.

Rosenberg, N.

1979 Perspectives on Technology. Cambridge: Cambridge University Press.

1982 Inside the Black Box: Technology and Economics. Cambridge: Cambridge University Press.

Schot, J., \& Bruheze de la, A.

2001 "The Mediated Design of Products, Consumption and Consumers in the Twentieth Century." In B. Lacner \& H. Rohracher (Eds.), Proceedings of the international summer academy on technology studies - user involvement in technological innovation july 8-13, 2001. Deutschlandsberg, Austria.

Soosalu, M.

1996 Turvaranneke (safety bracelet). Department of Industrial Design. Helsinki: Taideteollinen korkeakoulu.

Star, S. L., \& Griesemer, J.

1989 “Institutional Ecology, 'Translations' and Boundary Objects: Amateurs and Professionals in Berkeley's Museum of Vertebrate Zoology, 1907-1939." Social Studies of Science 19: 387-420.

Stewart, J., \& Williams, R.

2002 "The Wrong Trousers? Beyond the Design Fallacy: Social Learning and the User." Presentation held at the EASST Conference, University of York, 31 July - 2 August 2002.

Suchman, L.

1987 Plans and Situated Actions: The Problem of Human-machine Communication. Cambridge, England: Cambridge University Press.

2002 Located Accountabilities in Technology Production. http://www.comp.lancs. ac.uk/sociology/soc039ls.html, 2002 (28.02.2002). 
Suchman, L., Blomberg, J., Orr, J.E., \& Trigg, R.

1999 "Reconstructing Technologies as Social Practice." American Behavioral Scientist 43(3): 392-408.

Törmä, S., Nieminen, J., \& Hietikko, M.

2001 Ikääntyneiden itsenäistä suoriutumista tukevan teknologian arviointi käyttäjänäkökulmasta, turvahälytysjärjestelmät (The evaluation of technology supporting independent living of the elderly from the user perspective, alarm-systems) (Vol. 4/2001). Helsinki: Eduskunnan kanslia.

Wajcman, J.

1991 Feminism Confronts Technology. University Park: The Pennsylvania State University Press.

Wild, C., \& Kirsschner, A. (Eds.)

1994 Safety-alarm Systems, Technical Aids and Smart Homes (Vol. 8). Knegsel: Akontes Publishing.

Williams, R., Slack, R., \& Stewart, J.

2000 Social Learning in Multimedia, Final Report to European Commission. Edinburgh: RCSS.

Östlund, B.

1994 "Experiences with Safety-alarms for the Elderly in Sweden." In C. Wild \& A. Kirschner (Eds.), Safety-alarm Systems, Technical Aids and Smart Homes (pp. 47-58). Knegsel: Akontes Publishing.

1995 Gammal är älst. En studie om teknik i äldre menniskors liv. (The elderly are the oldest. A study of technology in the lives of elderly people.) Academic dissertation. University of Lindköping: Lindköping.

Sampsa Hyysalo

Center for Activity Theory and Developmental Work Research

University of Helsinki

sampsa.hyysalo@helsinki.fi 